\title{
THE JARIMATIKA METHOD ON MATH LEARNING: HOW TO IMPROVE MATH SKIL
}

\author{
Nurhaedah ${ }^{1}$, Rahmawati Patta ${ }^{2}$, Asmawati Triputri ${ }^{3}$ \\ \{Nurhaedah88@gmail.com ${ }^{1}$,rahmapatta02@gmail.com ${ }^{2}$ \} \\ ${ }^{1,2,3}$ Prodi PGSD FIP UNM, Indonesia
}

\begin{abstract}
The problem in this study is the low mathematics learning outcomes of elementary school students, especially in multiplication operations. This study aims to find out: (1) Implementation of Jarimatika method for mathematics subjects especially in multiplication operation, (2) Mathematics learning outcomes of elementary school, and (3) the influence of using Jarimatika method on mathematics learning outcome in students at elementary school. The approach used is a quantitative approach with the type of experimental research. The techniques and procedures for data collection are observation and tests. The results showed that the learning process carried out by teachers and students using the Jarimatika method for each meeting experienced an increase and was in Good category. The conclusion in this study is that the use of Jarimatika method influences the mathematics learning outcome at elementary school especially in multiplication operation.
\end{abstract}

Keyword: Jarimatika Method, Learning Outcomes, Mathematic

\section{INTRODUCTION}

Mathematics is one of the important lessons taught at the elementary school level. The function of mathematics learning is to equip students with the ability to think logically, analytically, systematically, critically and creatively as well as the ability to work together which is used to survive in an ever-changing and competitive situation. This is in accordance with the contents of the Minister of National Education Regulation No. 22/2006 that mathematics trains students' ability to think critically, critically, creatively, and analytically.

Mathematical functions which are so important do not correspond with reality, where a condition is found that most students in schools, especially elementary schools, consider learning mathematics the same as dealing with ghosts, because the impression is abstract, complicated, confusing, unpleasant, and make a headache. This, of course, will have an impact on further child development. Long-term studies from researchers at the National Institute of Child Health and Human Development explain that children who previously failed to achieve basic math skills in their first grade will experience the slowest development compared to their peers in terms of number system knowledge throughout the year the school [1]. Such conditions can be caused by the teaching and learning process that occurs in the classroom. The learning and teaching process involves the teacher and students. A teacher who becomes a student's point of attention in learning using less precise method, will have an impact on learning outcomes which are not optimal. One usable method to overcome this is to choose a teaching method that suits the characteristics of the students they teach. At the elementary school level, children aged 
between 7-12 years. According to Piaget, at that age the cognitive development of elementary school students entered the third stage. This stage is the concrete operational stage [2]. Students at this stage have the ability in the process of thinking to operate the rules of logic followed by concrete objects which are certainly able to be captured by the five senses. Therefore, students need to be stimulated in a tangible way in the learning process.

In line with the stages through, students need activities that require their own. This of course will make it easier for students to understand the learning in their path. One of the mathematical materials requires direct activities of students who use arithmetic operations. Arithmetic operations material play an important role, counting is needed in other fields of study such as physics, biology, chemistry, and other social sciences such as economics. In addition, in everyday life counting becomes very important because counting is used starting from simple activities such as counting money and other expenses. Count operation material is completed in terms of addition, preparation, multiplication, and division. One of the debates is the multiplication that students need to master as a basis for working on higher mathematical topics. Therefore, multiplication needs to be done in the right way or method.

Based on the observations of SDN Lariang Bangi II, Makassar City, in mathematics learning, especially for the multiplication, they still use the memorization method so that when their multiplication is checked by the teacher, only a few can pass completely. The researcher is initiative to provide teaching using the Jarimatika method to third grade elementary school students in mathematics, especially multiplication material. Third grade elementary school students need special attention because the student's numeracy ability is not yet adequate where the measurement used in solving correct questions takes 90 seconds [3]. This, of course, must be based on the concept of learning mathematics itself. Marilyn Burns and Baratta Lorton explained that one of the stages of the concept of mathematics learning is the level of concept understanding, where students learn through work experience or play with concrete things [4]. One method that is able to concretize something abstract is the Jarimatika method. Jarimatika method is a method of counting using the fingers. Students only need to use their hands to assist them in solving calculation problems. This is consistent with Piaget's theory that grade III students in elementary schools are still at the concrete operational stage.

This is in line with the research of Yuni which also explains that the Jarimatika method is able to increase students' numeracy speed as in the conclusion of their research that the use of Jarimatika can improve two-digit multiplication skills and learning outcomes of the third grade students at SDN 2 Tamansari academic year 2016/2017[5]. The formulation of the problems in this study are 1) How is the description of the Jarimatika method in mathematics of the third grade at Elementary School? 2) What is the description of the mathematics learning outcomes especially multiplication operation? 3) Is there an influence of the Jarimatika method on the learning outcomes of students elementary school?

\section{METHOD}

\section{A. Approach and Types of Research}

\section{Research Approach}

The approach used in this research was a quantitative approach. The quantitative approach had data in the form of numbers which are analyzed using statistics. This approach was used to provide information on the effect of certain treatments on others. 


\section{Types of Research}

This type of research is an experimental study using a quasi experimental design in the form of non equivalent control group design. Quasi experimental design was one of the designs of experimental research which was used to look for the effect of certain treatments on others under controlled conditions.

\section{B. Research Variable and Design}

\section{Research Variable}

The variables in this study consisted of the independent and dependent variables. The independent variable in this study is the Jarimatika method. Meanwhile, the dependent variable in this study is the mathematics learning outcomes of third grade elementary school students.

\section{Research Design}

This research design was in the form of non equivalent control group design. The design form shows as follows:

Table 3.1. Research Design

\begin{tabular}{llll}
\hline Group (Class) & Pre-Test & Treatment & Post-Test \\
\hline Experiment & $\mathrm{O}_{1}$ & $\mathrm{X}$ & $\mathrm{O}_{2}$ \\
\hline Control & $\mathrm{O}_{3}$ & - & $\mathrm{O}_{4}$ \\
\hline
\end{tabular}

\section{Operational Definition}

\section{Jarimatika Method}

Jarimatika method referred to in this study is a method using the fingers in solving arithmetic problems, especially multiplication.

2. Mathematics Learning Outcomes

Mathematical learning outcomes referred to in this study are the results or scores obtained by providing pre-test and post-test in mathematics learning.

\section{Population and Sample}

1. Population

The population in this study was all students of the third grade at SD Kompleks Lariang Bangi. SD Kompleks Lariang Bangi consists of 5 schools. The schools are SDN Lariang Bangi I, SDN Lariang Bangi II, SDN Lariang Bangi III, SD Lariang Bangi I Inpres and SD Lariang Bangi II.

2. Sample

The sample of this study was students of the third grade at SDN Lariang Bangi II as an experimental class and students of the third grade at SD Inpres Bertingkat Lariang Bangi I as a control class. The sampling steps in this study are (a) choosing two schools that have almost the same number of students, namely SDN Lariang Bangi II and SD Inpres Bertingkat Lariang Bangi I, (b) randomly selecting one of the two classes at schools selected as the experimental class, (c) the class not selected as the experimental class based on step b, automatically becomes the control class, and (d) the students involved from the two classes were the samples that investigated in this study. The following are the number of students from each school: 
Table 3.2: The Data of students SDN Lariang Bangi

\begin{tabular}{llll}
\hline School & $\begin{array}{l}\text { Male } \\
\text { Students }\end{array}$ & $\begin{array}{l}\text { Female } \\
\text { Students }\end{array}$ & Total \\
\hline SDN Lariang & 9 & 6 & 15 students \\
Bangi 2 & & 11 & 16 students \\
\hline $\begin{array}{l}\text { SDI Bertingkat } \\
\text { Lariang Bangi 1 }\end{array}$ & 5 & & 31 students \\
\hline Overall Total & & & \\
\hline
\end{tabular}

Source: SDN Lariang Bangi 2 and SDI Bertingkat Lariang Bangi 1

\section{E. Technique of Collecting Data}

\section{a. Observation}

Observations in this study were conducted to find out the description of the Jarimatika method which consists of observations of teachers and students. Observations made on the teacher include 6 aspects, namely opening, delivery of material using the Jarimatika method, giving examples of questions using the Jarimatika, the student discussion process, feedback, and closing.

The assessment of aspects conducted by the teacher was seen from how many indicators were met, if all indicators were met then the aspects carried out would be classified as good or scored 3. While observations for students consisted of 5 aspects namely paying attention to the teacher's explanation, being able to use teaching aids properly, ask unclear questions related to the material being taught, work on worksheets, and receive guidance from the teacher when working on worksheets. The results of the final assessment at each meeting would be categorized to make it easier to find out the description of the Jarimatika method. The category of the implementation of the method showed as follows:

Table 3.3 The category of the implementation of the method

\begin{tabular}{ll}
\hline Score & Category \\
\hline $69<\mathrm{x} \leq 100$ & Good \\
\hline $45<\mathrm{x} \leq 69$ & Enough \\
\hline $0 \leq \mathrm{x} \leq 45$ & Less \\
\hline & Source: Arikunto [6]
\end{tabular}

\section{b. Test}

Source: Arikunto [6]

The test used was multiple choice. The score for correct questions was 1 and the score for false questions was 0 . The test used was previously validated with field or empirical validation. Tests that had been tested in the field were analyzed using the biserial point formula to determine the validity of each item and the Kuder Richardson formula (KR20) to determine the reliability of the questions to be used. The results of field validation will be recapped in the following table:

Table3.4: The result of field validation by tests

\begin{tabular}{lll}
\hline Total of Test Questions & \multirow{2}{*}{ Deciduous Item } \\
\cline { 1 - 2 } Before Validation & After Validation & \\
\hline 40 numbers & 22 numbers & 18 numbers \\
\hline
\end{tabular}




\section{F. Technique of Data Analysis}

\section{Descriptive Statistical Analysis}

Descriptive statistical analysis in this study was used to describe student learning outcomes in mathematics learning both when treated using the Jarimatika method in experimental class learning and conventional learning in the control class. Descriptive statistics referred to in this study were describing the data acquisition of student learning outcomes in research such as frequency, average value (mean), median data (median), values that often appear (mode), range of values (range), standard deviations (standard deviation), lowest data value (minimum), and highest data value (maximum) using the Statistical Package for Social Science (SPSS) Version 20.0 system. The scale category interval learning outcomes for mathematics as follows.

Table 3.5. Guidelines for categorizing student learning outcomes[7]

\begin{tabular}{ll}
\hline Value Interval (Score 100) & Category \\
\hline $85-100$ & Very good \\
\hline $70-84$ & Good \\
\hline $56-69$ & Enough \\
\hline $41-55$ & Less \\
\hline $0-40$ & Very Less \\
\hline
\end{tabular}

\section{Inferential Statistical Analysis}

a. Assumption Test

1) Normality Test

Normality test was performed to determine the distribution of data in the variables that used in this study whether or not normally distributed. In this study, we wanted to find out whether the data about the influence of the Jarimatika method on student mathematics learning outcomes are normally distributed or not. The test used to determine data normality was the Kolmogorov-Smirnov test. This test was carried out with the help of SPSS Version 20. The method of decision making was if the $\mathrm{P}$ value $>0.05$ then the data was normally distributed and vice versa if the $\mathrm{P}$ value $<0.05$ then the data was not normally distributed.

2) Homogeneity Test

Homogeneity test was intended to show that the two or more sample data groups came from populations that had the same variance. The test used was the Levene's test with the help of SPSS Version 20. The method of decision making in this homogeneity test was if the $\mathrm{P}$ value $>0.05$ then the variance of each sample was the same (homogeneous). Meanwhile, if the value of $\mathrm{p}$ value $<0.05$ then the variance of each sample was not the same (not homogeneous).

\section{b. Hypotheses Test}

Testing the hypothesis in this study was to use an independent sample t-test. Independent sample t-test was used to compare two groups of means from two different samples (independent). The principle of this test was to find out whether there was a difference in the mean sample so before it was tested with an independent sample t-test, the conditions must be normally distributed and homogeneous. The following formula was the independent sample t-test [8] 


$$
\mathrm{t}_{\text {hitung }}=\frac{\overline{\mathrm{x}}_{1}-\overline{\mathrm{x}}_{2}}{S D \overline{\mathrm{x}}}
$$

Information:

: $t$ value calculated

$\mathrm{X} 1$ : value from group 1

$\mathrm{X} 2$ : value from group 2

SDX: standard error of both groups

To determine the selected hypotheses we see from the provisions that if the value of $\mathrm{p}$ value $>0.05$, then $\mathrm{H} 0$ was accepted and Ha was rejected. Meanwhile, if the value of $\mathrm{p}$ value $<0.05$ then $\mathrm{H} 0$ was rejected and Ha was accepted. In addition, decision making could be done by comparing the value of $\mathrm{t}$ count and $\mathrm{t}$ table. If $\mathrm{t}$ count $<\mathrm{t}$ table then $\mathrm{H} 0$ was accepted and $\mathrm{Ha}$ was rejected, conversely if $\mathrm{t}$ count $>\mathrm{t}$ table then $\mathrm{H} 0$ was rejected and Ha was accepted

\section{RESULTS AND DISCUSSIONS}

a. Student pretest data about the learning outcomes of the Experimental Class Mathematics

Students' pretest of learning outcomes in the experimental class was 15 research subjects. The following data was a description of the students' pretest scores in the experimental class

Table 4.1. Description of Student Pretest Score in Experiment Class

\begin{tabular}{ll}
\hline Descriptive Statistics & Statistical Value \\
\hline Total Samples & 15 \\
\hline Lowest Score & 27 \\
\hline Highest Score & 59 \\
\hline Mean & 40.53 \\
\hline Range & 32 \\
\hline Standard Deviation & 9.804 \\
\hline Median and mode & 41 and 41 \\
\hline
\end{tabular}

Based on table 4.1, it can be seen that the mean value of the experimental class of 15 students is 40.53; while the median value is 41 and mode is 41 . The standard deposit (standard deviation) is 9,804; the highest value (maximum) obtained is 59; the lowest (minimum) value obtained is 27; and the range between the highest value and the lowest value is 32 of the ideal score of 100 . The frequency distribution of pretest results of student learning outcomes of the experimental class can be seen in the following table:

Table 4.2. Distribution and Percentage of Pretest Scores for Student Learning Outcomes in Experimental Classes

\begin{tabular}{lllll}
\hline No. & Value Interval & Category & Frequency & Percentage \\
\hline 1 & $85-100$ & Very good & - & - \\
\hline 2 & $70-84$ & Good & - & - \\
\hline 3 & $56-69$ & Enough & 1 & $6,67 \%$ \\
\hline 4 & $41-55$ & Less & 9 & $60 \%$ \\
\hline 5 & $0-40$ & Very less & 5 & $33,33 \%$ \\
\hline Total & & & 15 & $100 \%$ \\
\hline
\end{tabular}


Based on the frequency distribution table, it is known that the number of students who get the category is quite as much as 1 person with a percentage of $6.67 \%$; the number of students who received the less category was 9 people with a percentage of $60 \%$; the number of students who received the category was very less as many as 5 people with a percentage of $33.33 \%$. Based on the results of the descriptive analysis that has been done it can be concluded that the results of the pretest in the experimental class are in the less category, this can be seen based on the number of students in the less category.

\section{b. Student pretest data about the learning outcomes of the Control Class Mathematics}

Students' pretest on learning outcomes in the control class consists of 16 research subjects. Data from the control class pretest results can be seen in the following table:

Table 4.3 Data pretest control class

\begin{tabular}{ll}
\hline Descriptive Statistics & Statistical Value \\
\hline Total Samples & 16 \\
\hline Lowest Score & 27 \\
\hline Highest Score & 64 \\
\hline Mean & 42.75 \\
\hline Range & 37 \\
\hline Standard Deviation & 13.364 \\
\hline Median & 45 \\
\hline Modus & 27 \\
\hline
\end{tabular}

Based on table 4.3, it can be seen that the average value (mean) of the control class of 16 students amounted to 42.75; while the median value is 45 and mode is 27 . The standard deposit (standard deviation) is 13,364; the highest value (maximum) obtained is 64; the lowest (minimum) value obtained is 27; and the range between the highest value and the lowest value is 37 from the ideal score of 100. The frequency distribution of pretest results of student learning outcomes of the experimental class can be seen in the following table:

Table 4.4. Distribution and Percentage of Pretest Scores for Student Learning Outcomes in the Control Class

\begin{tabular}{lllll}
\hline No. & Value Interval & Category & Frequency & Percentage \\
\hline 1 & $85-100$ & Very good & - & - \\
\hline 2 & $70-84$ & Good & - & - \\
\hline 3 & $56-69$ & Enough & 3 & $18,75 \%$ \\
\hline 4 & $41-55$ & Less & 8 & $50 \%$ \\
\hline 5 & $0-40$ & Very less & 5 & $31,25 \%$ \\
\hline Total & & & 16 & $100 \%$ \\
\hline
\end{tabular}

Based on the frequency distribution table, it is known that the number of students who get the category is enough as many as 3 people with a percentage of $18.75 \%$; the number of students who received the less category was 8 people with a percentage of $50 \%$; the number of students who received the category was very less as many as 5 people with a percentage of $31.25 \%$. Based on the results of the descriptive analysis that has been done it can be concluded that the results of the pretest in the control class are in the less category, this can be seen based on the number of students in the less category. 


\section{c. Students' posttest data about the learning outcomes of Experimental Class Mathematics}

Students' posttest on learning outcomes in the experimental class with a total of 15 research subjects. The following data is a description of students' posttest scores in the experimental class.

Table 4.5. Description of Student's Posttest Score in Experiment Class

\begin{tabular}{ll}
\hline Descriptive Statistics & Statistical Value \\
\hline Total Samples & 15 \\
\hline Lowest Score & 59 \\
\hline Highest Score & 82 \\
\hline Mean & 69.47 \\
\hline Range & 23 \\
\hline Standard Deviation & 6.243 \\
\hline Median & 68 \\
\hline Modus & 64 \\
\hline
\end{tabular}

Based on table 4.5, it can be seen that the mean value of the experimental class of 15 students is 69.47; while the median value is 68 and mode is 64 . The standard deposit (standard deviation) is 6,243 ; the highest value (maximum) obtained is 82 ; the lowest (minimum) value obtained is 59; and the range between the highest value and the lowest value is 23 from an ideal score of 100. The frequency distribution of posttest results of learning outcomes of experimental class students can be seen in the following table:

Table 4.6. Distribution and Percentage of Scores Posttest Student Learning Outcomes in Experimental

\begin{tabular}{lllll} 
& & \multicolumn{2}{c}{ Classes } & \\
\hline No. & Value Interval & Category & Frequency & Percentage \\
\hline 1 & $85-100$ & Very good & - & - \\
\hline 2 & $70-84$ & Good & 6 & $40 \%$ \\
\hline 3 & $56-69$ & Enough & 9 & $60 \%$ \\
\hline 4 & $41-55$ & Less & - & - \\
\hline 5 & $0-40$ & Very less & - & - \\
\hline Total & & & 15 & $100 \%$ \\
\hline
\end{tabular}

Based on the frequency distribution table, it is known that the number of students who received a good category were 6 students with a percentage of $40 \%$ and enough categories were 9 students with a percentage of $60 \%$. Based on the results of the descriptive analysis that has been done it can be concluded that the results of the posttest in the experimental class are in the sufficient category, this can be seen based on the number of students in the sufficient category.

\section{d. Students' posttest data about the learning outcomes of the Control Class Mathematics}

Students' posttest on learning outcomes in the control class consisted of 16 research subjects. The following data is a description of the students' posttest scores in the control class.

Table 4.7. Description of Student's Posttest Score in the Control Class

\begin{tabular}{ll}
\hline Descriptive Statistic & Statistical value \\
\hline Total Sample & 16 \\
\hline Lowest score & 41 \\
\hline Highest score & 73 \\
\hline Mean & 54.38 \\
\hline
\end{tabular}




\begin{tabular}{ll}
\hline Standard Deviation & 10.072 \\
\hline Median & 55 \\
\hline Modus & 55 \\
\hline
\end{tabular}

Based on table 4.7, it can be seen that the average value (mean) of the control class of 16 students amounted to 54.38; while the median value is 55 and mode is 55. The standard deposit (standard deviation) is 10,072; the highest value (maximum) obtained is 73 ; the lowest (minimum) value obtained is 41 ; and the range between the highest value and the lowest value is 32 of the ideal score of 100 . The distribution of the frequency of the results of the post-test learning outcomes of control class students can be seen in the following table:

Table 4.8. Distribution and Percentage of Scores Posttest Student Learning Outcomes in the Control Class

\begin{tabular}{lllll}
\hline No. & Value Interval & Category & Frequency & Percentage \\
\hline 1 & $85-100$ & Very good & - & - \\
\hline 2 & $70-84$ & Good & 1 & $6,25 \%$ \\
\hline 3 & $56-69$ & Enough & 4 & $25 \%$ \\
\hline 4 & $41-55$ & Less & 11 & $68,75 \%$ \\
\hline 5 & $0-40$ & Very less & - & - \\
\hline Total & & & 16 & $100 \%$ \\
\hline
\end{tabular}

Based on the frequency distribution table, it is known that the number of students who get the good category is 1 person with a percentage of $6.25 \%$; the number of students who get enough categories is 4 people with a percentage of $25 \%$; and the number of students who received the less category was 11 people with a percentage of $68.75 \%$. Based on the results of the descriptive analysis that has been done it can be concluded that the results of the posttest in the control class are in the less category, this can be seen based on the number of students in the less category.

\section{e. The Effect of Jarimatika Method on Student Learning Outcomes}

The influence of Jarimatika method on student learning outcomes is known through the results of inferential statistical analysis. This inferential statistical analysis consists of assumption testing and hypothesis testing.

1) Normality Test

Normality test is conducted to find out whether the data in the experimental class and the control class are normally distributed or not. Processing normality test using the help of IBM SPSS Statistics Version 20. Normality test in this study using Kolmogorov-Smirnov. Data is said to be normally distributed if the probability value at the Kolmogorov-Smirnov test output is greater than the determined $\alpha$ value, which is $5 \%(0.05)$. The summary of data from the pretest and posttest normality test results in the experimental class and the control class can be seen in the following table

Table 4.9. Test Results for Pretest and Posttest Normality of Experiment Class and Control class

\begin{tabular}{lll}
\hline Data & Probability Value & Information \\
\hline Pretest Experiment Class & 0,174 & $0,174>0,05=$ normal \\
\hline Pretest Control Class & 0,113 & $0,113>0,05=$ normal \\
\hline Posttest Experiment Class & 0,138 & $0,138>0,05=$ normal \\
\hline Posttest Control Class & 0,090 & $0,090>0,05=$ normal \\
\hline
\end{tabular}


Based on these data, it shows that the results of the pretest and posttest experimental and control classes are normally distributed. This can be seen from the results of normality tests on the four data which obtained a probability value greater than 0.05 . Thus, it can be concluded that the experimental class and control class data are normally distributed.

\section{2) Homogeneity Test}

Homogeneity test is performed to find out whether the data obtained from both samples are homogeneous or not. The data is said to be homogeneous if the probability value at the Levene Statistics output is greater than the specified $\alpha$ value, which is 5\% (0.05). Summary of the data of the pretest and posttest homogeneity test results in the experimental class and the control class can be seen in the following table.

Table 4.10. Homogeneity Test Results for Pretest and Posttest for Experiment and Class

\begin{tabular}{lll}
\hline Data & Probability Value & Information \\
\hline Pretest of experiment and control class & 0,316 & $0,316>0,05=$ homogeneous \\
\hline Posttest of experiment and control class & 0,094 & $0,094>0,05=$ homogeneous \\
\hline
\end{tabular}

Based on these data, it shows that the homogeneity test results of the experimental class pretest and control class as well as the posttest of the experimental class and control class are said to be homogeneous because the probability value is greater than 0.05 . After obtaining the homogeneity test results of the experimental class and the control class, then the parametric test or the $t$ test is performed because the conditions that must be met before conducting the parametric test or the t test are the two groups of data tested must be homogeneous.

\section{3) Hypothesis Test}

\section{a. Independent Sample T-Test Pretest of Experiment and Control Class}

This analysis was carried out by testing the results of the pretest of the experimental class and the control class using the help of the IBM SPSS Statistics Version 20. The data requirements are said to be significant if the probability value is less than 0.05. This analysis aims to determine differences in student learning outcomes between the experimental class and the control class before being given treatment. The results of the independent sample t-test pretest values of the experimental class and the control class are as follows:

Table 4.11. Independent Sample T-Test Pretest of Experiment and Control Class

\begin{tabular}{|c|c|c|c|c|}
\hline Data & $\mathbf{T}$ & Df & Probability Value & Information \\
\hline $\begin{array}{l}\text { Pretest of Experimental and } \\
\text { Pretest of Control class }\end{array}$ & $-0,524$ & 29 & 0,605 & $\begin{array}{c}0,605>0,05=\mathrm{No} \\
\text { difference }\end{array}$ \\
\hline
\end{tabular}

Based on the table, information is obtained that the probability value is greater than 0.05 , meaning that there is no significant difference in learning outcomes between the experimental class and the control class before being given treatment. If the calculated t value of -0.571 compared with the value of t table 2.045 obtained through the table by seeing the value of $\alpha=5 \%$ and $\mathrm{df}=29$, then $\mathrm{t}$ count has a value smaller than $t$ table $(-0.524<2.045)$. Thus, it can be concluded that $t$ count $<t$ table shows that the pretest data obtained were not significantly different. 


\section{b. Independent Sample T-Test Posttest of Experiment and Control Class}

This analysis aims to determine differences in student learning outcomes between classes that follow learning by using the Jarimatika method and classes that follow learning without using the Jarimatika method. This analysis was done by testing the results of the experimental class posttest and control class posttest. This analysis was carried out using the help of the IBM SPSS Statistical Variant 20 program. Data requirements are said to be different if the probability value is less than 0.05 . The results of the independent sample t-test analysis of the experimental class posttest and posttest control class values are as follows.

Table 4.12. Independent Sample T-Test Posttest of Experiment and Control Class

\begin{tabular}{lllll}
\hline Data & T & Df & Probability Value & Information \\
\hline $\begin{array}{l}\text { Posttest } \text { of Experiment and Control } \\
\text { Class }\end{array}$ & 4,973 & 29 & 0,000 & $0,000<0,05=$ Has \\
\end{tabular}

Based on the table, information is obtained that the probability value is smaller than 0.05. This shows that there are significant differences in student learning outcomes between classes that follow learning using the Jarimatika method and classes that follow learning without using the Jarimatika method. If the value of $t$ count is 4.973 compared to the value of t table of 2.045 by looking at the value of $\alpha=5 \%$ and $\mathrm{df}=29$, then $\mathrm{t}$ count has a value greater than t table $(4.973>2.045)$. Thus, it can be concluded that $\mathrm{t}$ arithmetic $>\mathrm{t}$ table, this means that the posttest data obtained shows there is a significant difference.

Based on the description, the null hypothesis (H0) is rejected, that means there is no significant effect between the Jarimatika method on the mathematics learning outcomes of third grade students at SD Kompleks Lariang Bangi, Makassar City and the alternative hypothesis (Ha) is accepted, namely there is a significant influence between the methods Jarimatika on mathematics learning outcomes of third grade students at SD Kompleks Lariang Bangi, Makassar District, Makassar City.

Mathematics is one of the subjects that most elementary school students have difficulty in completing, even up to tertiary institutions. In basic arithmetic, there are four arithmetic operations that students must understand, namely addition, subtraction, multiplication and division. The four arithmetic operations are interrelated to one another. Add and subtract calculation operations that are considered easy then multiplication and division. Pretest results before the application of treatment there are still many students who have not fluently memorized the case. To overcome this problem, a method that is well known to the people is using the Jarimatika method. The principle of method selection as stated [4] that the method has principles of motivation, experience, integrated understanding, and encouraging.

Jarimatika method applies the principles to learning that refers to methodical active and general learning principles, including playing while learning, learning from close to far, learning from the concrete to the abstract, and learning with the nearest media.

The results showed that the Jarimatika method gives a significant influence on student mathematics learning outcomes, especially in multiplication calculation operations. A method will certainly provide several advantages for users. According to Septi Peni Wulandari, the Jarimatika method has several advantages, namely Jarimatika provides a visualization of the counting process that makes children or students easy to do, the movements of the fingers will attract students' interest because it makes students happy when doing so where children feel as if they are playing while learning and feel challenged with Jarimatika technique, Jarimatika is 
relatively not burdensome brain memory when used by students, the tool does not need to be purchased, will never be left behind or forgotten where to store it, and will not be confiscated when the exam uses it [9]. Jarimatika method needs to be used with a number of reasons, as for the following reasons [3]: The ability to count students in primary schools quickly and precisely needs to get serious attention because of the ability to count students in primary schools especially class I, II, and III are inadequate. The measurements we use each can be completed correctly in 90 seconds

\section{CONCLUSION}

1. The learning process took place during four meetings and were observed using an observation sheet. Observation on teachers for the first meeting was quite sufficient with a percentage of $66.66 \%$. The second meeting, the learning process was classified as good with a percentage of $77.77 \%$. The third meeting, the learning process was classified as good with a percentage of $83.33 \%$. At the fourth meeting or the last meeting, the learning process was classified as good with a percentage of $94.44 \%$. While observations on students obtained results that showed that the first meeting of the learning process by using the Jarimatika method is quite sufficient with a percentage of $53.33 \%$. The second and third meetings, the learning process is classified as good with the same percentage of $73.33 \%$. The fourth meeting, the learning process was classified as good with a percentage of $86.66 \%$.

2. Student learning outcomes in the experimental class are more improved than student learning outcomes in the control class. This is evidenced by the posttest scores in the experimental class as many as 9 students in enough category and in the good category as many as 6 people. Whereas the control class was in the less category as many as 11 people, the category was quite 4 people, and the good category was 1 person.

3. There is an influence of the use of the Jarimatika method. This is because there is a significant difference in the probability value between the experimental class using the Jarimatika method and the control class without using the Jarimatika method where the probability value obtained is 0.00 which means the value is smaller than 0.05 . In addition, the calculated $t$ value obtained with df 29 is 4.973 . This shows that $t$ count $(4,973)>t$ table $(2,045)$ so that $\mathrm{HO}$ is rejected and $\mathrm{Ha}$ is accepted without seeing positive (+) and negative.

\section{BIBLIOGRAPHY}

[1] Y. Satya, "Matematika Masih jadi Teror Siswa-Perlu Metode Baru," Harian Ekonomi, 2014.

[2] M. Daruma, A. Razak. Sulaiman Samad, Perkembangan Peserta Didik. Makassar: FIP UNM, 2009.

[3] Z. and A. M. Aqib, Kumpulan Metode Pembelajaran Kreatif dan Inovatif. Bandung: Sarana Toturial Nurani Sejahtera, 2016.

[4] M. Faizi, Ragam Media Mengajarkan Eksakta pada Murid. Yogyakarta: Diva Press, 2013.

[5] Y. dan N. S. Mariyati, "Efektivitas Penggunaan Jarimatika dalam Meningkatkan Keterampilan Berhitung Matematika Kelas III SDN Tamansari," J. Teknol. Pendidik., vol. 2, p. 34, 2017.

[6] Suyadi, Strategi Pembelajaran Pendidikan Karakter. Bandung: Remaja Rosdakarya, 2013. 
[7] S. Arikunto, Dasar-dasar Evaluasi Pendidikan. Jakarta: Bumi Aksara, 2006.

[8] F. R. Utsman, Panduan Statistika Pendidikan. Yogyakarta: Diva Press, 2015.

[9] Suparni, "Metode Jarimatika Kaitannya dengan Pembelajaran Operasi Hitung Perkalian di SD/MI,” J. Logaritma, vol. 3, pp. 147-153, 2015.

\section{ACKNOWLEDGEMENTS}

The author thanks the rector of Makassar state university, head of the Primary School Teacher Education study program, who has provided his support in the preparation of this paper, PGSD students, principals and teachers of Lariang Bangi Elementary School who are the place of research and all those whom the author cannot mention one by one. Thank you. 